\title{
Relationship between Anchorage-Independent Growth and Cytochalasin B-Induced Multinucleation in Cloned BHK-21/C13 Cells and Their Chemical Transformants
}

\author{
Hiroya Kamei \\ Central Research Institute, The Japan Tobacco and Salt Public Corporation, \\ 6-2 Umegaoka, Midori-ku, Yokohama 227, Japan
}

\begin{abstract}
The relationships between anchorage-independent growth and cytochalasin B (CB)-induced multinucleation in cloned BHK-21 cells and their chemical transformants were studied. Clones of BHK-21 cells derived from flat colonies grown on plastic, that were selected for their extremely low growth on agar plates ( $\mathrm{Ag}^{-}$clones), had low $\mathrm{CB}$-multinucleated cell rates ( $\%$ of cells with more than 3 nuclei), whereas parent BHK-21 cells could grow on an agar plate and had high CB-multinucleated ceil rates. Transformants (agar colonies) were induced in a $\mathrm{Ag}^{-}$clone (L77) after treatment with MNNG and several days of expression time. At least two types of transformants were distinguishable by their agar colony morphologies; globular and dispersing. The clones derived from the transformants retained their ability to grow on an agar plate. Most showed increased CB-multinucleated cell rates when compared to parent $\mathrm{L} 77$ cells irrespective of the agar colony type. These results indicate that anchorage-independent growth and CB-multinucleation are closely related in BHK-21 cells and their clones, and that both properties can be induced simultaneously during chemical transformation.
\end{abstract}

Anchorage-independent growth observed as colony formation in a semi-solid medium $(17,26)$ is a widely recognized property of transformed cells in avian and mammalian cell cultures in vitro. Embryonic cells treated with chemical carcinogens could grow in soft agar when they were aquiring tumorigenicity in long-term cultures $(2,6,9,12,16)$, although some exceptions have been found $(1,8)$. Multinucleation in the presence of CB (4), an inhibitor of the microfilament (28), is another property which distinguishes transformed cells from normal or preneoplastic cells $(13,14,19$, $20,23,29)$. Normal or preneoplastic cells become binucleated by $C B$, whereas transformed cells become multinucleated. A close correlation between CB-multinucleation and anchorage-independent growth has been observed in RNA-tumor virus-transformed cells (23), but the relationship between these two properties during chemical transformation has not been examined in detail. I have tried to clarify the

Abbreviations used: CB, cytochalasin B; BHK-21, BHK-21/C13; MNNG, N-methyl-N'-nitroN-nitrosoguanidine; MEM, Eagle's minimum essential medium; FCS, fetal calf serum; DMSO, dimethylsulfoxide; AIR, anchorage independency rate; $\mathrm{Ag}^{-}$clone, a clone which has normal ability for growth on plastic but extremely low or no ability on an agar plate. 
relationship in an established cell line, BHK-21 cells. BHK-21 cells, a Syrian hamster fibroblastic cell line (25), have been used for chemical transformations $(3,5,7,10$, $22,27)$ and chromosome transfer experiments (24) in vitro with anchorage-independent growth as a marker. I here report that $\mathrm{Ag}^{-}$clones derived from BHK-21 cells have a low CB-multinucleated cell rate and that most of the transformants induced by a chemical carcinogen, and which aquire the ability for anchorage-independent growth, have increased CB-multinucleated cell rates.

\section{MATERIALS AND METHODS}

Cells and cell culture. BHK-21 cells at passage 55 were obtained from the American Type Culture Collection (U.S.A.). These cells and their clones were cultured in MEM supplemented with $10 \%$ heat-inactivated FCS (Gibco, U.S.A.) in humidified air with $5 \% \mathrm{CO}_{2}$ at $37^{\circ} \mathrm{C}$. Cells were harvested with $0.25 \%$ trypsin- $0.03 \%$ EDTA-phosphate buffered saline $\left(\mathrm{Ca}^{2+}\right.$ and $\mathrm{Mg}^{2+}$-free) before they reached confluence and were passaged at $1: 10$ or $1: 20$ splits. Cell numbers were counted with a hemocytometer without staining. BHK-21 cells and their clones from early passages were stocked at $-75^{\circ} \mathrm{C}$ in the culture medium containing $10 \%$ DMSO. In all the experiments, early passage cells and the same lot of FCS were used.

Growth on an agar plate and on a plastic surface. The abilities of cells to grow were tested both on an agar plate (15) and on a plastic surface. The agar plate was made of $10 \mathrm{ml}$ of $0.5 \%$ agar (agar noble, Difco, U.S.A.)-MEM-20\% FCS in an 85-mm bacterial dish (Eiken Kizai, Japan). Cells $\left(4 \times 10^{2}\right.$ to $\left.2 \times 10^{5}\right)$ in $0.2 \mathrm{ml}$ of MEM- $20 \%$ FCS were plated on this agar layer. After incubation for 3 weeks, colonies which had a diameter of more than $0.30 \mathrm{~mm}$ were counted. Small colonies and cell aggregates visible to the naked eye but less than 0.30 $\mathrm{mm}$ in diameter also were counted as microcolonies. At the time of plating on the agar layer, 200 to 1,000 cells in $5 \mathrm{ml}$ of MEM- $20 \%$ FCS were plated on a $60-\mathrm{mm}$ plastic dish (Corning, U.S.A.) and incubated for 8 days. Colonies of more than 50 cells were counted after fixation with methanol and staining with Giemsa's solution. Data were expressed as averages of 3 dishes unless otherwise stated. The ratio (in percentage) of plating efficiency ( $\%$ of colonies per plated cells) on the agar plate (Aga PE) per that on the plastic surface (Pla PE) was the anchorage-independency rate (AIR).

The number of surviving cells on the agar plates were calculated as the percent of living cells and cell aggregates per the total cells, which included dead cells. Bright cells on agar plates under phase-contrast microscopy were considered living cells.

Selection of $\mathrm{Ag}^{-}$clones. BHK-21 cells were plated in a microtestplate with 96 wells (Falcon, U.S.A.) at 23 to 26 cells per plate. After 10 to 12 days, single colonies which showed a flat morphology were selected and recovered by trypsinization. These cells were cultured for about 2 passages then assayed for Aga PE and Pla PE. Aga PE was assayed at 2 cell densities; about $10^{5}$ cells and $2 \times 10^{3}$ cells per plate, 2 plates being used for each assay. Clones which had a low Aga PE $(<0.01 \%)$ and a high Pla PE $(>20 \%)$ were selected as $\mathrm{Ag}^{-}$clones.

Transformation by MNNG. MNNG (Wako Junyaku, Japan) first was dissolved in DMSO (for spectroscopy, Merck, West Germany) then in MEM. $\mathrm{Ag}^{-}$cells $\left(5 \times 10^{5}\right)$ in $10 \mathrm{ml}$ of the culture medium were plated on a $90-\mathrm{mm}$ plastic dish (Falcon, U.S.A.). Three days later, monolayer cells found near the confluence were washed with MEM and incubated with MEM containing MNNG $(0,5,10$, or $20 \mu \mathrm{M})$ and DMSO $(0.03 \%)$ for $2 \mathrm{~h}$ at $37^{\circ} \mathrm{C}$. After this treatment, cells were washed with MEM, harvested by trypsinization, and assayed for transformation immediately ( 0 day) or after an expression time of 4 or 8 days. To obtain the expression time, I plated treated cells $\left(2 \times 10^{5}\right)$ in $10 \mathrm{ml}$ of the culture medium on a $90-\mathrm{mm}$ 
plastic dish which was then cultured for 4 days ( 4 day) or for an additional 4 days after replating ( 8 day). Transformation was assayed by plating $2 \times 10^{5}$ cells on an agar plate, 5 plates for each dose point. Colonies which grew on the agar plate were considered transformants. At each assay, Pla PE was assayed simultaneously to standardize the number of transformants by cells which are capable to grow on plastic surface. The toxicity of MNNG was evaluated by the decrease in the Pla PE of MNNG-treated cells compared to the control (the Pla PE of the control, MNNG $0 \mu \mathrm{M}$, was $100 \%$ ).

Cloning from the agar colony. Colonies distant from other colonies, or living cells, were picked up with a small pipette. These colonies were cultured and passaged in normal medium without agar.

Multinucleation test with $C B$. Cells $\left(2.5 \times 10^{4}\right.$ or $\left.1.5 \times 10^{4}\right)$ in $2.5 \mathrm{ml}$ of the culture medium were plated on a $35-\mathrm{mm}$ plastic dish (Falcon, U.S.A.). After 1 or 2 days, the medium was replaced with fresh medium containing CB (0 or $1.0 \mu \mathrm{g} / \mathrm{ml}$, Sigma, U.S.A.) and $0.1 \%$ DMSO. After cultivation for 4 to 7 days with $\mathrm{CB}$, the cells were fixed with methanol and stained with Giemsa's solution. More than 300 cells per dish were examined for the number of nuclei ( 1 to 7 , or more). Data are the averages for 2 dishes. Degenerated cells, round-up cells and cells in growing populations were not counted. The micro-nucleus and any protrusion of the nucleus were counted as a single nucleus. The percentage of cells with more than 3 nuclei per total counted cells was the multinucleated cell rate.

\section{RESULTS}

Selection of $\mathrm{Ag}^{-}$clones and their responses to $\mathrm{CB}$. Relatively flat colonies were selected from 455 colonies of BHK-21 cells grown on microtestplates, and 44 clones were obtained which were numbered L50 to L93. The Aga PE in this group showed a wide distribution from 0.001 to $0.8 \%$. Clones L53, L77, L80, and L92 were extremely low in Aga PE, but high in Pla PE; therefore, they were named $\mathrm{Ag}^{-}$clones.

The abilities for growth of the BHK-21 cells and $\mathrm{Ag}^{-}$cells were shown in Table 1 . The AIR of the BHK-21 cells was 0.70 to $5.2 \%$, whereas the values for $\mathrm{Ag}^{-}$cells were 0.0004 to $0.01 \%$. When microcolonies were included in the calculation of AIR, the values for $\mathrm{BHK}-21$ cells ranged from 1.1 to $8.4 \%$, and values for $\mathrm{Ag}^{-}$cells ranged

TABLE 1. The ABILITIES For GROWTH OF BHK-21 Cells AND THEIR AG ${ }^{-}$ClONES

\begin{tabular}{|c|c|c|c|c|c|}
\hline \multirow{2}{*}{ Cell } & \multicolumn{2}{|c|}{$\begin{array}{l}\text { Plating efficiency } \\
\text { on agar plate }(\%)\end{array}$} & \multirow{2}{*}{$\begin{array}{c}\begin{array}{c}\text { Plating efficiency } \\
\text { on plastic }(\%)\end{array} \\
\text { B }\end{array}$} & \multicolumn{2}{|c|}{ Anchorage independency rate } \\
\hline & A (Colony) & $\begin{array}{l}\mathrm{A}^{\prime}(\text { Colony }+ \\
\text { Microcolony })\end{array}$ & & A/B & $\mathbf{A}^{\prime} / \mathbf{B}$ \\
\hline BHK-21 ${ }^{\mathrm{a}}$ & $\begin{array}{c}0.17-3.1 \\
\quad(1.3)\end{array}$ & $\begin{array}{l}0.26-5.0 \\
\quad(2.3)\end{array}$ & $\begin{array}{c}24-59 \\
(39)\end{array}$ & $\begin{array}{l}0.70-5.2 \\
\quad(3.1)\end{array}$ & $\begin{array}{c}1.1-8.4 \\
(5.2)\end{array}$ \\
\hline L 53 & $<0.0009$ & 0.006 & 55 & $<0.002$ & 0.01 \\
\hline $\mathrm{L} 77^{\mathrm{a}}$ & $\begin{array}{c}0.0002-<0.002 \\
(0.0009)\end{array}$ & $\begin{array}{c}<0.002-0.018 \\
\quad(0.008)\end{array}$ & $\begin{array}{c}21-41 \\
(34)\end{array}$ & $\begin{array}{c}0.0004-<0.005 \\
(0.003)\end{array}$ & $\begin{array}{c}<0.005-0.050 \\
\quad(0.023)\end{array}$ \\
\hline L 80 & 0.004 & 0.063 & 29 & 0.01 & 0.22 \\
\hline L92 & 0.003 & 0.053 & 38 & 0.008 & 0.14 \\
\hline
\end{tabular}

a Data for these cells are given as ranges and averages (in parentheses) of 5 (BHK-21) or 4 (L77) experiments. The value 0.002 was used to calculate the averages for $\mathrm{L} 77$ cells of $<0.002$. 
from $<0.005$ to $0.22 \%$. For the $\mathrm{Ag}^{-}$cells, the surviving cells on the agar plates varied from 3 to $9 \%$ at 3 weeks.

L77 cells from an $\mathrm{Ag}^{-}$clone which had been cultured on an agar plate for about 3 weeks are shown in Fig. 1. Most cells remained as single cells (Fig. 1A). But some microcolonies or small cell aggregates were found in the region of high cell density (Fig. 1B). The response of $\mathrm{L} 77$ cells to $\mathrm{CB}$ is shown in Fig. 2. Cell division was suppressed and many cells became binucleated with CB. The degree of multinucleation in BHK-21 cells and $\mathrm{Ag}^{-}$cells is shown in Table 2. The CB-multinucleated cell rates for $\mathrm{BHK}-21$ cells were from 21 to $24 \%$, whereas those for the $\mathrm{Ag}^{-}$clones ranged from $<1$ to $5 \%$.

Transformation in L77 cells by MNNG. Transformation in L77 cells due to treatment with MNNG is shown in Fig. 3. Data corrected with Pla PE values also are shown to cancel out the effect of the toxicity of MNNG. The toxicity of MNNG $(5,10$, or $20 \mu \mathrm{M})$ was $45 \%, 70 \%$, or $76 \%$ at 0 days, and $11 \%, 41 \%$, or $35 \%$ at 4 days, but the toxicity was not significant at 8 days. Many transformants appeared in cells treated with MNNG after an expression time of 4 to 8 days, and the number of transformants increased with an increase in the dose of MNNG (Fig. 3). After 8 days of expression time, the number of transformants (values corrected with Pla PE) appearing in MNNG $(5,10$, or $20 \mu \mathrm{M})$-treated cells were 7-, 9-, or 18-fold more, respectively, than in the control cells. Few transformants were detected in cells treated with MNNG that had been assayed without an expression time. The colony morphology on an agar plate was mainly globular or discoid (Fig. 4A), but some colonies were found to be dispersing with an accumulation of something at their centers (Fig. 4B).

Properties of the transformants. The agar colonies induced from $\mathrm{L} 77$ cells with MNNG were isolated and numbered L77-Ag1 to L77-Ag12. Clones from these colonies, which differed in morphology or in their history of treatment were selected and examined. The abilities of these L77-Ag cells to grow are shown in Table 3.
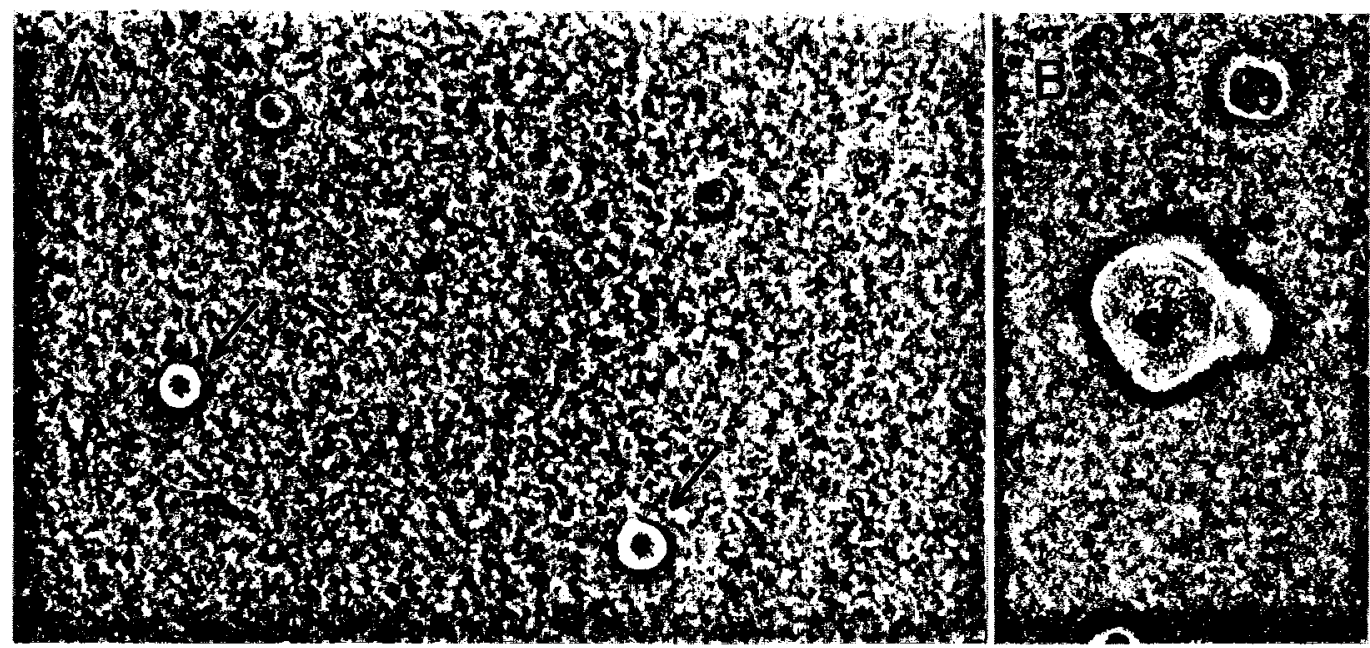

Fig. 1. L77 cells cultured on an agar plate. Cells were plated at $2 \times 10^{4}$ cells per dish then cultured for 25 days. A: Well dispersed L77 cells. Arrows indicate living cells which are bright. B: L77 cells at high cell densities. Phase contrast. $\times 143$ 

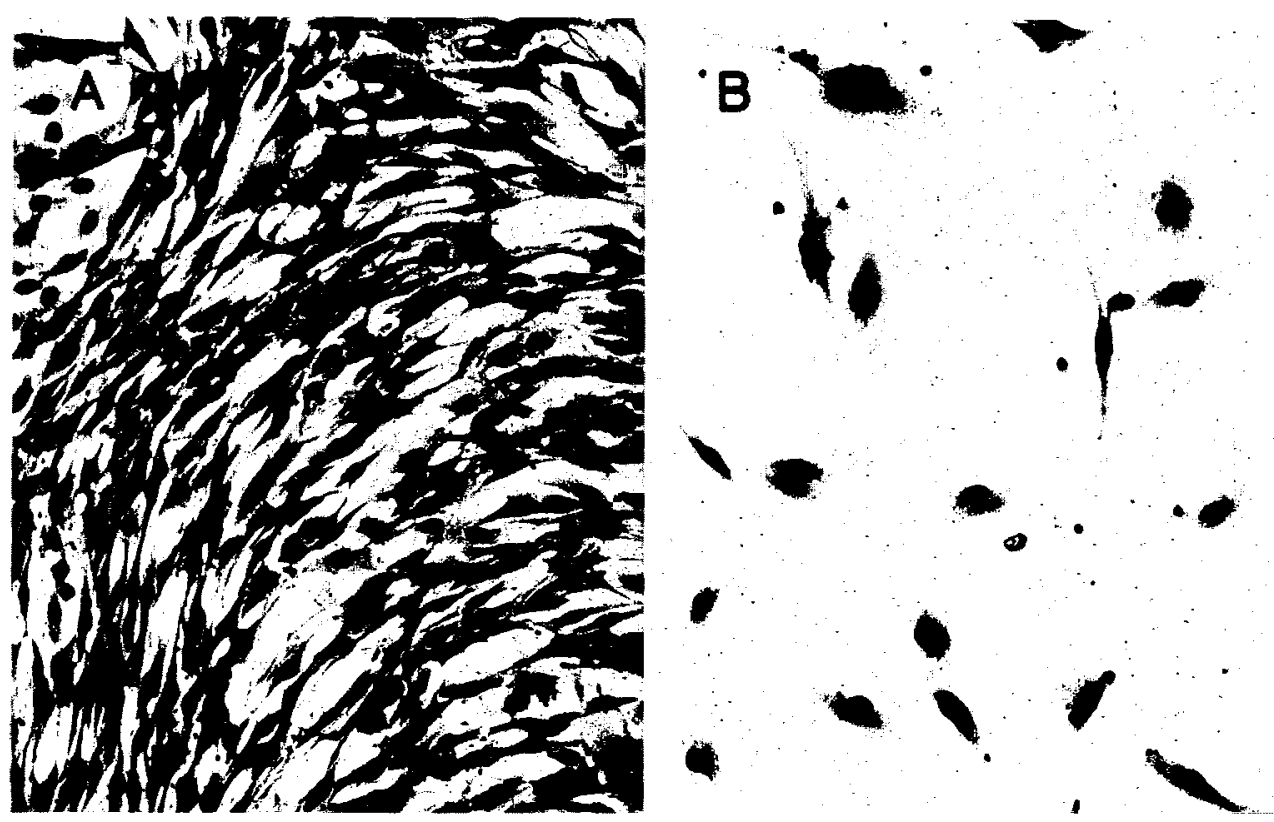

Fig. 2. Response of L77 cells to CB. Cells were cultured with DMSO (0.1\%) (A) or CB $(1 \mu \mathrm{g} / \mathrm{ml})$ and DMSO (0.1\%) (B) for 4 days, then fixed, and stained. $\times 143$

TABLE 2. MUltinucleation By CB IN BHK-21 CellS AND THeIr AG- Clones

\begin{tabular}{|c|c|c|c|c|c|c|c|c|c|}
\hline \multirow{2}{*}{ Cell } & \multirow{2}{*}{$\begin{array}{l}\text { Culture } \\
\text { with CB } \\
\text { (days) }\end{array}$} & \multicolumn{7}{|c|}{$\%$ of cells with various numbers of nuclei } & \multirow{2}{*}{$\begin{array}{l}\text { Multinucleated } \\
\text { cell rate }(\%)\end{array}$} \\
\hline & & 1 & 2 & 3 & 4 & 5 & 6 & $\geqq 7$ & \\
\hline \multirow[t]{3}{*}{ BHK-21 } & 0 & 95 & 5 & $<1$ & 0 & 0 & 0 & 0 & $<1$ \\
\hline & 4 & 28 & 48 & 11 & 8 & 2 & 1 & 3 & 24 \\
\hline & 7 & 33 & 46 & 10 & 5 & 3 & 1 & 3 & 21 \\
\hline \multirow[t]{2}{*}{$\mathbf{L} 53$} & 0 & & & & & & & & $\mathrm{ND}^{\mathrm{c}}$ \\
\hline & 4 & 47 & 53 & 1 & $<1$ & 0 & 0 & 0 & 1 \\
\hline \multirow[t]{3}{*}{ L 77} & 0 & 97 & 3 & 0 & 0 & 0 & 0 & 0 & 0 \\
\hline & 4 & 57 & 41 & 2 & $<1$ & 0 & 0 & 0 & 2 \\
\hline & 7 & 43 & 56 & 1 & 1 & 0 & 0 & 0 & 1 \\
\hline \multirow[t]{3}{*}{ L 80} & 0 & 94 & 6 & $<1$ & 0 & 0 & 0 & 0 & $<1$ \\
\hline & 4 & 64 & 36 & $<1$ & 0 & 0 & 0 & 0 & $<1$ \\
\hline & 7 & 62 & 37 & 1 & 0 & 0 & 0 & 0 & 1 \\
\hline \multirow[t]{3}{*}{ L 92} & 0 & 93 & 6 & 1 & 0. & 0 & $<1$ & 0 & 1 \\
\hline & 4 & 46 & 49 & 4 & 1 & $<1$ & $<1$ & 0 & 5 \\
\hline & 6 & 43 & 52 & 5 & $<1$ & $<1$ & 0 & 0 & 5 \\
\hline
\end{tabular}

a CB at $1.0 \mu \mathrm{g} / \mathrm{ml}$.

b Percentage of cells with more than 3 nuclei.

c Not done. 


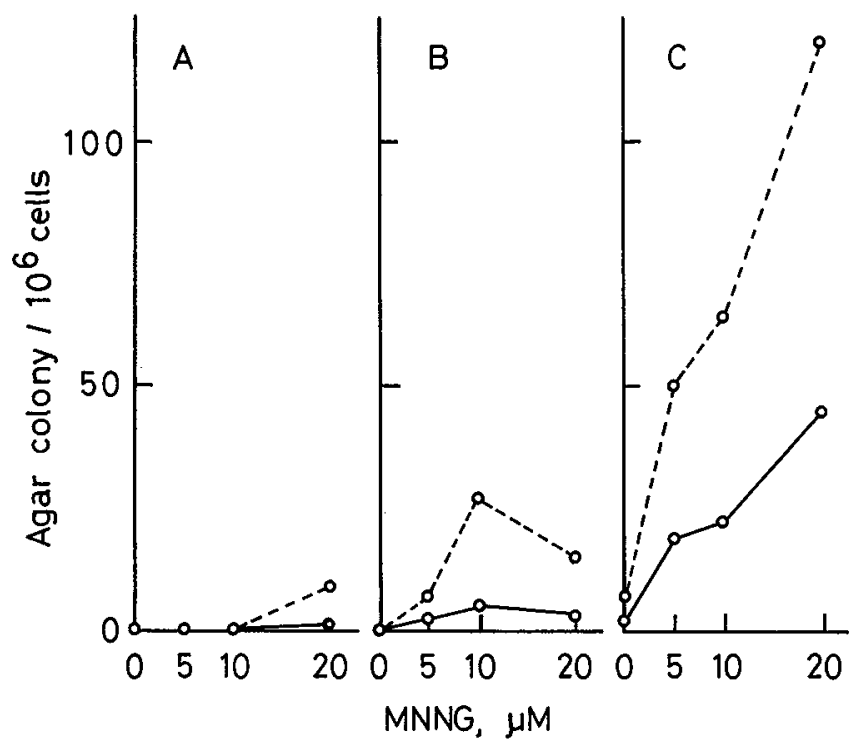

Fig. 3. Transformation in L77 cells by MNNG. L77 cells treated with MNNG for $2 \mathrm{~h}$ were washed, then recovered and assayed with or without further cultivation in normal medium. A: Assayed immediately after treatment ( 0 day). B: Assayed at 4 days. $\mathrm{C}$ : Assayed at 8 days. $\mathrm{O}-\mathrm{O}$, Agar colony $/ 10^{6}$ cells plated; $\bigcirc---\bigcirc$, Agar colony $/ 10^{6}$ cells capable of growth on a plastic surface.

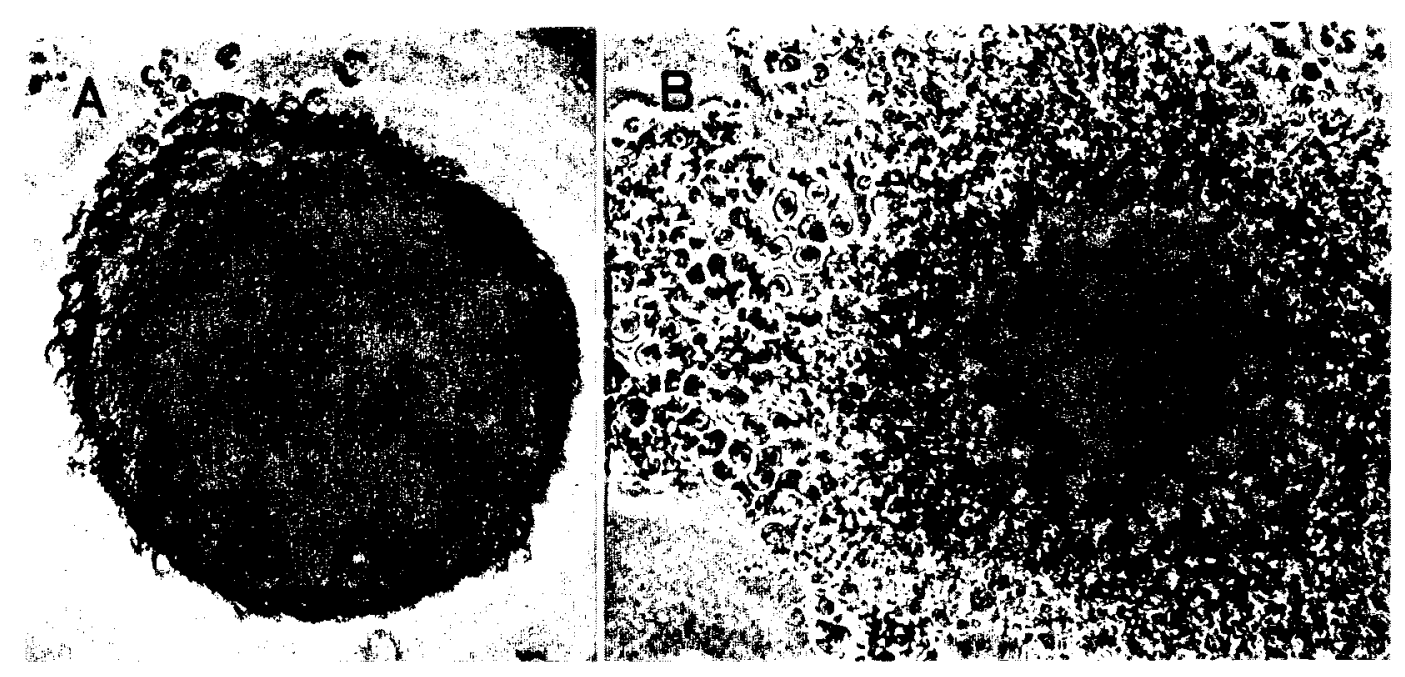

Fig. 4. Agar colonies induced in L77 cells by MNNG. L77 cells were treated with MNNG $(20 \mu \mathrm{M})$ and cultured in normal medium for 8 days, after which they were cultured on an agar plate for 28 days. A: Globular colony. B: Dispersing colony with an accumulation at its center. Only the part of the colony that includes its center is shown. Phase contrast. $\times 143$ 
TABLE 3. THE ABILITIES FOR GROWTH OF CLONES FROM AGAR COLONIES INDUCED IN L77 CELLS BY MNNG

\begin{tabular}{|c|c|c|c|c|c|c|c|}
\hline \multirow[t]{2}{*}{ Cell } & \multirow{2}{*}{$\begin{array}{l}\text { History } \\
\text { of } \\
\text { treatment }\end{array}$} & \multirow{2}{*}{$\begin{array}{l}\text { Morphology of } \\
\text { agar colony at } \\
\text { isolation }\end{array}$} & \multicolumn{2}{|c|}{$\begin{array}{l}\text { Plating efficiency on } \\
\text { agar plate }(\%)\end{array}$} & \multirow{2}{*}{$\begin{array}{c}\begin{array}{c}\text { Plating } \\
\text { efficiency } \\
\text { on plastic } \\
(\%)\end{array} \\
\text { B }\end{array}$} & \multicolumn{2}{|c|}{$\begin{array}{l}\text { Anchorage } \\
\text { independency } \\
\text { rate }(\%)\end{array}$} \\
\hline & & & A (Colony) & $\begin{array}{l}\text { A' (Colonyt } \\
\text { Microcolony) }\end{array}$ & & $\mathbf{A} / \mathbf{B}$ & $\mathbf{A}^{\prime} / \mathbf{B}$ \\
\hline L 77-Ag 1 & $\begin{array}{l}\text { MNNG } \\
20 \mu \mathrm{M}\end{array}$ & Dispersing ${ }^{a}$ & 22 & 32 & 64 & 34 & 50 \\
\hline L 77-Ag 3 & $\begin{array}{l}\text { MNNG } \\
20 \mu \mathrm{M}\end{array}$ & Dispersing & $<0.08$ & 0.4 & 8 & $<1$ & 5 \\
\hline L 77-Ag 5 & $\begin{array}{l}\mathrm{MNNG} \\
10 \mu \mathrm{M}\end{array}$ & Globular & 0.09 & 0.19 & 19 & 0.5 & 1.0 \\
\hline $\operatorname{L~77-Ag~} 7$ & $\begin{array}{l}\text { MNNG } \\
20 \mu \mathrm{M}\end{array}$ & $\begin{array}{l}\text { Globular to } \\
\text { discoid }\end{array}$ & $<0.08$ & 0.7 & 46 & $<0.2$ & 2 \\
\hline L 77-Ag 11 & $\begin{array}{l}\text { MNNG } \\
10 \mu \mathrm{M}\end{array}$ & Dispersing & $\mathrm{NC}^{\mathrm{b}}$ & 13 & 33 & $\mathrm{NC}$ & 41 \\
\hline $\mathrm{L} 77-\mathrm{Ag} 12$ & $\begin{array}{l}\text { MNNG } \\
10 \mu \mathrm{M}\end{array}$ & $\begin{array}{l}\text { Globular, surrour } \\
\text { with free cells }\end{array}$ & 0.48 & 0.58 & 13 & 3.8 & 4.6 \\
\hline
\end{tabular}

a L77-Ag1 cells were larger than L77-Ag3 cells.

b Not counted.

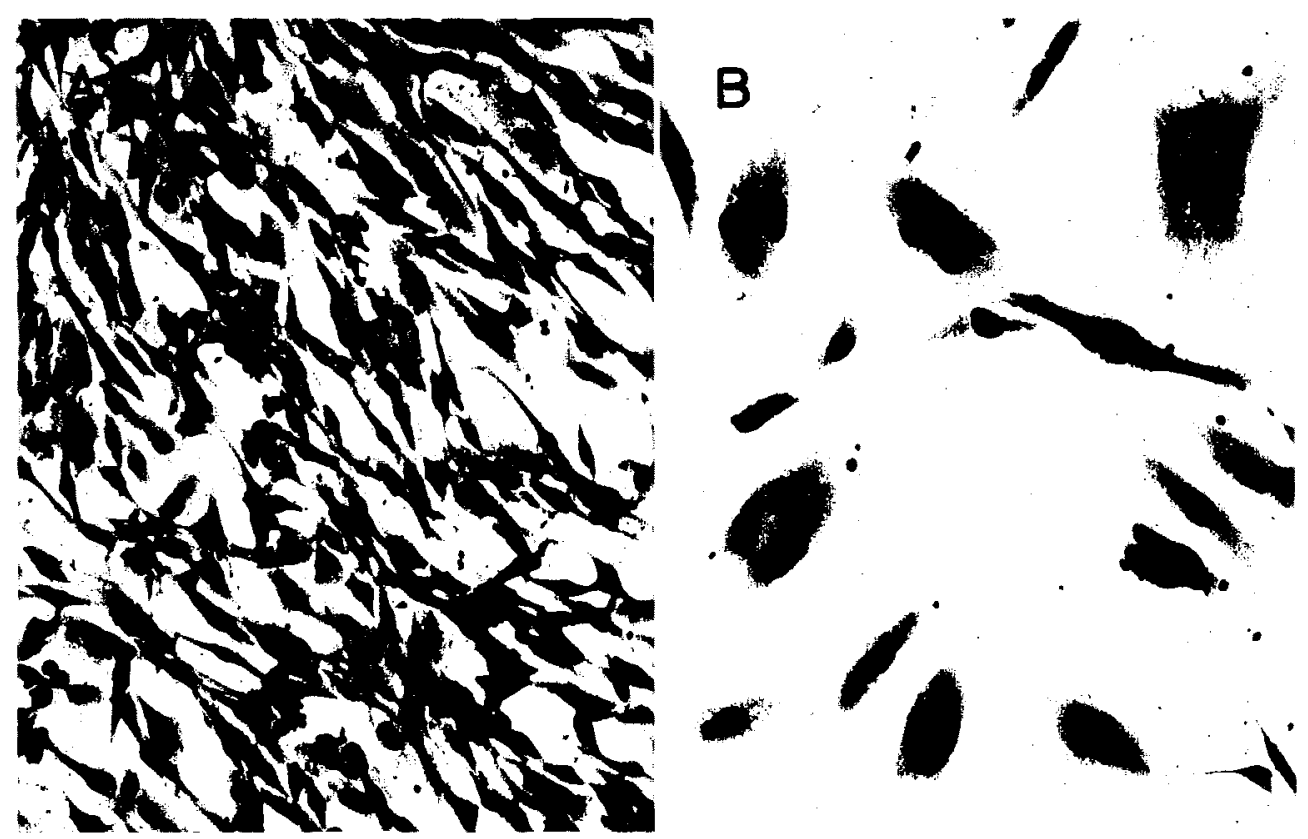

Fig. 5. Response of L77-Ag11 cells to CB. Cells were cultured with DMSO ( $0.1 \%$ ) (A) or CB $(1 \mu \mathrm{g} / \mathrm{ml})$ and DMSO (0.1\%) (B) for 4 days, then fixed and stained. $\times 143$ 
TABle 4. MultinuCleation by CB in ClONES From AgAR COLONIES INDUCED IN L77 CELLS BY MNNG

\begin{tabular}{|c|c|c|c|c|c|c|c|c|c|}
\hline \multirow{2}{*}{ Cell } & \multirow{2}{*}{$\begin{array}{l}\text { Culture } \\
\text { with CB } \\
\text { (days) }\end{array}$} & \multicolumn{7}{|c|}{$\%$ of cells with various numbers of nuclei } & \multirow{2}{*}{$\begin{array}{l}\text { Multinucleated } \\
\text { cell rate }{ }^{b}(\%)\end{array}$} \\
\hline & & 1 & 2 & 3 & 4 & 5 & 6 & $\geqq 7$ & \\
\hline \multirow[t]{3}{*}{ L 77-Ag 1} & 0 & 96 & 3 & 1 & 0 & $<1$ & 0 & $<1$ & 1 \\
\hline & 4 & 42 & 44 & 9 & 4 & 1 & 1 & 1 & 15 \\
\hline & 7 & 39 & 43 & 10 & 4 & 2 & 1 & 1 & 18 \\
\hline \multirow[t]{3}{*}{ L 77-Ag 3} & 0 & 90 & 8 & 1 & $<1$ & $<1$ & $<1$ & 0 & 1 \\
\hline & 4 & 55 & 43 & 2 & 0 & $<1$ & 0 & 0 & 2 \\
\hline & 7 & 53 & 44 & 3 & 1 & 0 & 0 & 0 & 3 \\
\hline \multirow[t]{3}{*}{ L 77-Ag 5} & 0 & 87 & 13 & 1 & 0 & 0 & $<1$ & $<1$ & 1 \\
\hline & 4 & 36 & 51 & 9 & 4 & 1 & $<1$ & $<1$ & 14 \\
\hline & 7 & 29 & 54 & 9 & 5 & 1 & $<1$ & 1 & 17 \\
\hline \multirow[t]{3}{*}{ L 77-Ag 7} & 0 & 97 & 3 & 1 & $<1$ & 0 & 0 & 0 & 1 \\
\hline & 4 & 20 & 74 & 5 & 1 & $<1$ & 0 & 0 & 6 \\
\hline & 7 & 25 & 66 & 7 & 2 & 1 & $<1$ & 1 & 10 \\
\hline \multirow[t]{3}{*}{ L 77-Ag 11} & 0 & 91 & 8 & 1 & $<1$ & 0 & 0 & $<1$ & 2 \\
\hline & 4 & 23 & 46 & 15 & 8 & 3 & 2 & 3 & 31 \\
\hline & 7 & 19 & 48 & 15 & 8 & 5 & 1 & 4 & 33 \\
\hline \multirow[t]{3}{*}{$\mathrm{L} 77-\mathrm{Ag} 12$} & 0 & 71 & 23 & 3 & 2 & $<1$ & $<1$ & 1 & 6 \\
\hline & 4 & 29 & 40 & 17 & 9 & 2 & 2 & 1 & 31 \\
\hline & 7 & 34 & 40 & 15 & 7 & 3 & 1 & 1 & 27 \\
\hline
\end{tabular}

a $\mathrm{CB}$ at $1.0 \mu \mathrm{g} / \mathrm{ml}$.

b Percentage of cells with more than 3 nuclei.

The L77-Ag cells retained their ability to grow on an agar plate, but to various degrees. Their AIRs ( $\left.\mathrm{A}^{\prime} / \mathrm{B}\right)$ were 1.0 to $50 \%$ and higher than those of $\mathrm{L} 77$ cells, $<0.005$ to $0.050 \%$. For most clones, the morphology of the colonies grown on an agar plate was the same as that when the clone was isolated. Only L77-Ag7 cells formed both globular and dispersing colonies. The response of L77-Ag11 cells to $\mathrm{CB}$ is shown in Fig. 5. Many multinucleated cells with more than 3 nuclei appeared in the presence of CB. The degree of multinucleation in L77-Ag cells is shown in Table 4. Regardless of their agar-colony type, most L77-Ag cells showed increased multinucleated cell rates ( 6 to $33 \%$ ) as compared to L77 cells ( 1 to $2 \%$ ). Only L77Ag3 cells still had low rates ( 2 to $3 \%$ ).

\section{DISCUSSION}

BHK-21 cells could grow on an agar plate and could form many multinucleated cells in the presence of $\mathrm{CB}$, as if these BHK-21 cells already had been transformed. $\mathrm{But}$, the $\mathrm{Ag}^{-}$clones isolated from these cells showed low $\mathrm{CB}$-multinucleation, evidence that the isolated $\mathrm{Ag}^{-}$clones were non-transformed cells. These results can be explained by the assumption that BHK-21 cells are composed of non-transformed cells and spontaneously transformed cells which have accumulated during the many passages $(11,18)$. 
The transformation of $\mathrm{L} 77$ cells by MNNG required an expression time as also reported for cloned BHK-21 cells (3). But, in uncloned BHK-21 cells (27) or in another type of clone which form microcolonies in soft agar (10), no experimental setting of expression time was necessary for inducing colony formation in soft agar. Therefore, most of the L77 cells transformed to form agar colonies may be cells which cannot form microcolonies on an agar plate.

Interestingly, the transformants did not have uniform agar colony morphology; at least two types were distinguishable, globular and dispersing. These types seem to be genetically stable for each clone as the agar colonies of most L77-Ag cells had the same morphology as the parent agar colonies isolated for cloning. My findings suggest that the transformation detected as the induction of agar colony formation is a mixture of at least two genetic changes (mutations and/or other changes); one change produces L77 cells which can grow on an agar plate as a globular colony, the other produces dispersing colonies.

Most transformants showed increased CB-multinucleation, whatever their agarcolony morphology. This suggests that, regardless of the primary affecting sites of cell structure and metabolism, some genetic changes related to microfilament systems (the target of CB) gives cells the ability for anchorage-independent growth. There are, however, other possibilities such as the change in anchorage-independency being induced preferentially in 1 to $2 \%$ of the L77 cells which already have been able to multinucleate with CB. Further studies are necessary to clarify this point.

CB-multinucleated cell rate for only one transformant (L77-Ag3) remained low. Whether this phenomenon represents an occasional exception or another type of transformant is not clear. Clones from agar colonies of BHK-21 cells with low levels of CB-multinucleation also have been reported by O'Neill (21).

Anchorage-independent growth and CB-multinucleation are closely related properties in BHK-21 cells and their clones, although there are exceptions. Because CB-multinucleation increased in most anchorage-independent transformants, both these transformation-related properties may be induced by the same genetic change(s). Chemical transformation in L77 cells, with anchorage-independency as a marker, may be an important step in malignant transformation in vitro.

\section{REFERENCES}

1. Alfred, L.J. Chemical carcinogen-induced alterations in the potentials of cultured animal cells. Nature 214, 732-734, 1967

2. Barrett, J.C. and P.O.P. Ts'o. Evidence for the progressive nature of neoplastic transformation in vitro. Proc. Natl. Acad. Sci. U.S.A. 75, 3761-3765, 1978

3. Bouck, N. and G. Di MaYorca. Somatic mutation as the basis for malignant transformation of BHK cells by chemical carcinogens. Nature 264, 722-727, 1976

4. CARTER, S.B. Effects of cytochalasins on mammalian cells. Nature 262, 261-264, 1967

5. Di Mayorca, G., M. Greensblatt, T. Trauthen, A. Soller and R. Giordano. Malignant transformation of BHK 21 clone 13 cells in vitro by nitrosamines -a conditional state. Proc. Natl. Acad. Sci. U.S.A. 70, 46-49, 1973

6. Evans, C.H. and J.A. Dipaolo. Neoplastic transformation of guinea pig fetal cells in culture induced by chemical carcinogens. Cancer Res. 35, 1035-1044, 1975

7. Fradkin, A., A. JANOFF, B. P. LANE and M. Kuschner. In vitro transformation of BHK 21 cells grown in the presence of calcium chromate. Cancer Res. 35, 1058-1063, 1975

8. Freedman, V.H. and S. SHIN. Isolation of human diploid cell variants with enhanced colonyforming efficiency in semisolid medium after a single-step chemical mutagenesis. J. Natl. 
Cancer Inst. 58, 1873-1875, 1977

9. Huberman, E., S. Salzberg, and L. Sachs. The in vitro induction of an increase in cell multiplication and cellular life span by the water-soluble carcinogen dimethylnitrosamine. Proc. Natl. Acad. Sci. U.S.A. 59, 77-82, 1968

10. IshiI, Y., J. A. Elliott, N. K. Mishra and M. W. Lieberman. Quantitative studies of transformation by chemical carcinogens and ultraviolet radiation using a subclone of BHK 21 clone 13 Syrian hamster cells. Cancer Res. 37, 2023-2029, 1977

11. JARrett, O. and I. MACPherson. The basis of the tumorigenicity of BHK 21 cells. Int. J. Cancer 3, 654-662, 1968

12. Kakunaga, T. and J. Kamahora. Properties of hamster embryonic cells transformed by 4-nitroquinoline-1-oxide in vitro and their correlations with the malignant properties of the cells. Biken J. 11, 313-332, 1968

13. Katsuta, H. and T. TAKaOKa. Carcinogenesis in tissue culture 30: Malignant transformation of normal rat liver cells treated with diethylnitrosamine in tissue culture, with special reference to the differential effects of cytochalasin B on various cells with and without tumorigenicity. Japan. J. Exp. Med. 49, 187-198, 1979

14. Kelly, F. and J. SAmbrook. Different effect of cytochalasin B on normal and transformed mouse cells. Nature New Biol. 242, 217-219, 1973

15. KUROKI, T. Colony formation of mammalian cells on agar plates and its application to Lederberg's replica plating. Exp. Cell Res. 80, 55-62, 1973

16. Lasne, C., A. Gentil and I. Chouroulinkov. Two-stage malignant transformation of rat fibroblasts in tissue culture. Nature 247, 490-491, 1974

17. Macpherson, I. and L. Montagnier. Agar suspension culture for the selective assay of cells transformed by polyoma virus. Virology 23, 291-294, 1964

18. MARIN, G. Origin and rate estimation of the spontaneous loss of anchorage dependence of growth in BHK 21 cells. Exp. Cell Res. 125, 31-36, 1980

19. Medina, D., C. J. Oborn, and B. B. Asch. Distinction between preneoplastic and neoplastic mammary cell populations in vitro by cytochalasin B-induced multinucleation. Cancer Res. 40, 329-333, 1980

20. O'NeILl, F.J. Control of nuclear division in normal, but not in neoplastic mouse cells. Cancer Res. 34, 1070-1073, 1974

21. O’NeILl, F.J. Loss of controlled nuclear division in BHK 21 cells passed in vivo. Cancer Res. 36, 2019-2024, 1976

22. Purchase, I.F.H., E. Longstaff, J. Ashby, J. A. Styles, D. Anderson, P. A. Lffevre and F.R. WeSTwOod. An evaluation of 6 short-term tests for detecting organic chemical carcinogens. Br. J. Cancer 37, 873-959, 1978

23. Somers, K.D. and M.M. Murphey. Multinucleation in the presence of cytochalasin B by RNA tumor virus-transformed cells. Cancer Res. 40, 4410-4414, 1980

24. Spandidos, D.A. and L. Siminovitch. Transfer of anchorage independence by isolated metaphase chromosomes in hamster cells. Cell 12, 675-682, 1977

25. Stoker, M. and I. MACPHERSOn. Syrian hamster fibroblast cell line $B H K 21$ and its derivatives. Nature 203, 1355-1357, 1964

26. Stoker, M., C. O’Neill, S. Berryman and V. Waxman. Anchorage and growth regulation in normal and virus-transformed cells. Int. J. Cancer 3, 683-693, 1968

27. Styles, J.A. A method for detecting carcinogenic organic chemicals using mammalian cells in culture. Br. J. Cancer 36, 558-563, 1977

28. Wessells, N.K., B.S. Spooner, J.F. Ash, M.O. Bradley, M.A. Luduena, E.L. Taylor, J.T. Wrenn and K. M. YamadA. Microfilaments in cellular and developmental processes; contractile microfilament machinery of many cell types is reversibly inhibited by cytochalasin B. Science 171, 135-143, 1971

29. Wright, W.E. and L. HAyflick. Formation of anucleate and multinucleate cells in normal and SV 40 transformed WI-38 by cytochalasin B. Exp. Cell Res. 74, 187-194, 1972

(Received for publication, January 22, 1982) 